\section{Michigan Technological

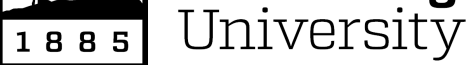

Michigan Technological University Digital Commons@Michigan Tech

5-1986

\title{
Dynamic deformation of volcanic ejecta from the Toba caldera: Possible relevance to Cretaceous/Tertiary boundary phenomena
}

\author{
Neville L. Carter \\ Texas A \& M University - College Station \\ Charles B. Officer \\ Texas A \& M University - College Station \\ Craig A. Chesner \\ Michigan Technological University \\ William I. Rose \\ Michigan Technological University
}

Follow this and additional works at: https://digitalcommons.mtu.edu/geo-fp

Part of the Geology Commons, Mining Engineering Commons, and the Other Engineering Commons

\section{Recommended Citation}

Carter, N. L., Officer, C. B., Chesner, C. A., \& Rose, W. I. (1986). Dynamic deformation of volcanic ejecta from the Toba caldera: Possible relevance to Cretaceous/Tertiary boundary phenomena. Geology, 14(5), 380-383. http://dx.doi.org/10.1130/0091-7613(1986)14\%3C380:DDOVEF\%3E2.0.C0;2

Retrieved from: https://digitalcommons.mtu.edu/geo-fp/127

Follow this and additional works at: https://digitalcommons.mtu.edu/geo-fp

Part of the Geology Commons, Mining Engineering Commons, and the Other Engineering Commons 


\title{
Dynamic deformation of volcanic ejecta from the Toba caldera: Possible relevance to Cretaceous/Tertiary boundary phenomena
}

\author{
Neville L. Carter \\ Center for Tectonophysics, Texas A \& M University, College Station, Texas 77843 \\ Charles B. Officer \\ Earth Sciences Department, Dartmouth College, Hanover, New Hampshire 0.3755 \\ Craig A. Chesner, William I. Rose \\ Geology Department, Michigan Technological University, Houghton, Michigan 49931
}

\begin{abstract}
Plagioclase and biotite phenocrysis in ignimbrites erupted from the Toba caldera, Sumatra, show microstructures and textures indicative of shock stress levels higher than 10 GPa. Strong dynamic deformation has resulted in intense kinking in biotite and, with increasing shock intensity, the development in plagioclase of planar features, shock mosaicism, incipient recrystallization, and possible partial melting. Microstructures in quartz indicative of strong shock deformation are rare, however, and many shock lamellae, if formed, may have healed during post-shock residence in the hot ignimbrite; they might be preserved in ash falls. Peak shock stresses from explosive silicic volcanism and other endogenous processes may be high and if so would obviate the need for extraterrestrial impacts to produce all dynamically deformed structures, possibly including shock features observed near the Cretaceous/Tertiary boundary.
\end{abstract}

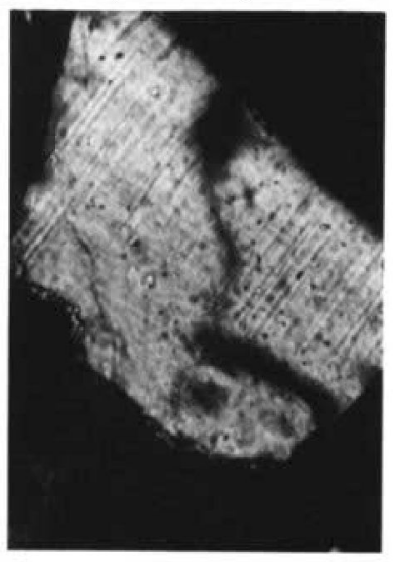

A

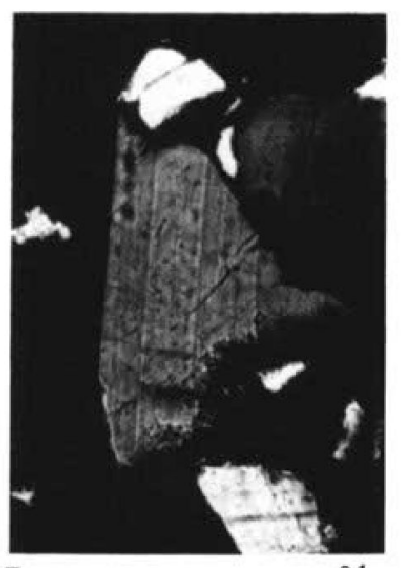

0.1

Figure 1. Photomicrographs of shockproduced microstructures in Toba ignimbrites. Scale bars are in millimetres. $A$ and B: Planar features (northeast-trending linear features in A; northsouth-trending linear features in B) in quartz grains in specimens $\mathrm{T}-32$ and $\mathrm{T}-92$, respectively; crossed nicols. C and D: Irregularly and highly kinked and fragmented biotite grains in specimens T-94B and 10.680 , respectively; planepolarized light.
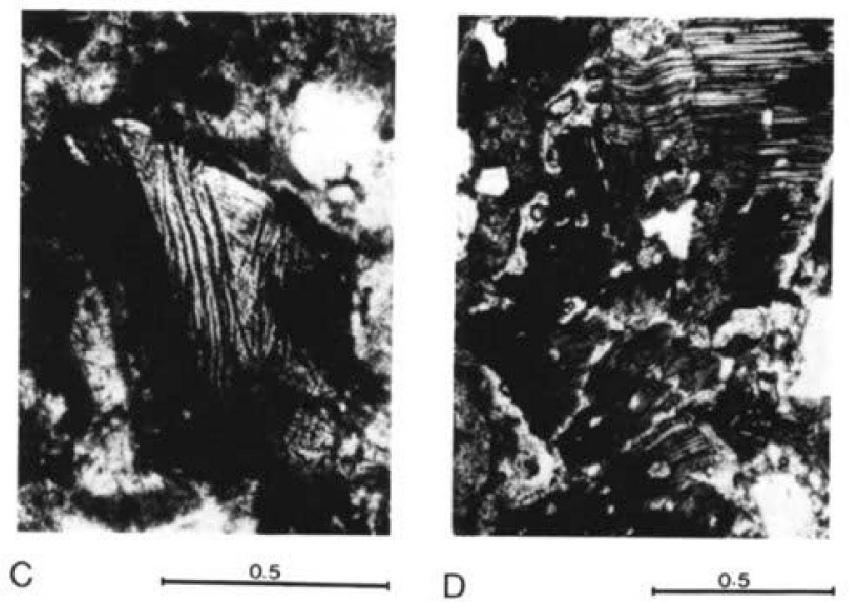

\section{INTRODUCTION}

Alvarez et al. (1980) have argued that massive biological changes at the Cretaceous/ Tertiary $(\mathrm{K} / \mathrm{T})$ boundary, at $65 \mathrm{Ma}$, were probably caused by impact of a $10-\mathrm{km}$ diameter asteroid. Part of the resulting ejecta reached the stratosphere and considerably reduced the amount of sunlight reaching Earth for several years. A brief cessation of photosynthesis resulted in widespread floral and faunal extinction. The primary evidence cited for this cataclysmic event rests on anomalously high concentrations of platinum-group metals, especially iridium, in marine clays near the $\mathrm{K} / \mathrm{T}$ boundary at several localities around the globe. Although the $200-\mathrm{km}$-diameter crater that would have resulted from such an event has not yet been found, support for the impact hypothesis has come from the discovery by Bohor et al. $(1984,1985)$ of shock lamellae in 15 quartz grains at or near the $\mathrm{K} / \mathrm{T}$ boundary near Brownie Butte in east-central Montana and in 10 grains at the Pontedazzo site in Umbria, Italy. Possible occurrences of shocked quartz at the boundary in other areas are listed by Bohor et al. (1985), and closely spaced microfractures, attributed to $<10 \mathrm{GPa}$ shock stresses, have been observed by Izett and Pillmore (1985) at nine sites in the Raton Basin, New Mexico and Colorado, as well as at $25 \mathrm{~cm}$ below the $\mathrm{K} / \mathrm{T}$ boundary at Brownie Butte.

To date, the best-documented data for shocked quartz at the K/T boundary are those for Brownie Butte, where 61 intersecting sets dominantly parallel to the rhombohedra $\underline{\omega}(10 \overline{1} 3)$ and $\underline{\pi}$ (1012) are observed, and for Pontedazzo, where 46 sets dominantly parallel to $\underline{\omega}$ and with a subordinate set parallel to $\Upsilon(0441)$ occur. Such planar features, first observed in quartz at the Clearwater Lake impactite, Canada (McIntyre, 1962), and observed since in many cryptoexplosion structures (Short and Bunch, 1968), have been described in detail (e.g., Carter, 1965, 1968a, 1968b; Bunch, 
1968; Chao, 1968; Engelhardt et al., 1968; Robertson et al., 1968). These microstructures, which first appeared in quartz in granodiorite that had undergone peak shock pressures of 6 $\mathrm{GPa}$ during the Hardhat nuclear explosion (Short, 1968a), are abundant in orthoquartzite and granodiorite shocked in the pressure range 7-40 GPa in high explosive and chemical implosion experiments (Short, 1968b) and were induced in quartz single crystals shock-loaded with a $20-\mathrm{mm}$ powder gun to pressures greater than $10 \mathrm{GPa}$ (Horz, 1968). They may occur in single or multiple sets (Short, 1968a; Carter, 1968b), the number of sets apparently increasing with increasing shock intensity (Short, 1968b). The lamellar structures are composed of short-range order (glassy) material induced during small shear displacements, are unquestionably of dynamic origin, and apparently require deviatoric stresses greater than $5 \mathrm{GPa}$, about two orders of magnitude higher than average lithospheric tectonic stresses.

Since publication of the Alvarez et al. (1980) impact hypothesis, many articles and symposia have appeared that discuss, among other phenomena, climatic and photosynthetic effects of such an ejected global dust cloud (e.g., Reid, 1981; Kent, 1981), the effects of sedimentation and bioturbation on elemental redistributions (e.g., review by Officer and Drake, 1985), and floral and faunal changes at the $\mathrm{K} / \mathrm{T}$ boundary (e.g., Axelrod, 1981; Officer and Drake, 1983; Smit and Romein, 1985; McLean, 1985).

Many of these discussions have attempted to establish that the geologic record indicates a transitional period of biological changes over a time span of $10^{4}$ to $10^{5}$ yr rather than an instantaneous event. This viewpoint also appears to be supported strongly by apparent significant differences in ages of the marine and continental K/T boundaries (e.g., McLean, 1985). A peak in volcanic activity at about $65 \mathrm{Ma}$ (near the time of eruption of the basalts of the Deccan Traps, India) seems to be the most reasonable alternative (e.g., Officer and Drake, 1985; McLean, 1985; Officer et al., 1985; H. R. Nasland, C. B. Officer, and G. B. Johnson, in prep.) and could account, by a large number of environmental changes, for the selective extinctions observed, as well as for the iridium anomaly. However, evidence for strong shock deformation, although extensively researched for cryptoexplosion structures during the 1960s and for returned lunar samples in the early 1970s, has not been searched for or obtained for volcanic explosions or eruptions, to our knowledge. The obvious place to begin such an investigation is to examine rock samples from the most violent type of volcanic eruptions, those occurring at silicic calderas. The last Toba eruption in Sumatra, which occurred $75000 \mathrm{yr}$ ago, may have been one of the largest eruptions of this type on Earth; thus, its deposits are primary candidates for this preliminary study.

\section{TOBA VOLCANISM}

The Toba caldera in northern Sumatra was first described as a volcano-tectonic depression by Bemmelen (1939) and has since been studied by Smith and Bailey $(1962,1968)$ and others. Toba lies along a destructive plate margin and is about $100 \times 30 \mathrm{~km}$, elongated in a northwest-southeast direction parallel to the active volcanic front in Sumatra. In areal extent, the Toba caldera is more than 50 times greater than Krakatoa and in volume it is about $\mathbf{4 0 0}$ times greater (Kent, 1981). A prominent ash horizon associated with the youngest Toba eruption occurs in deep-sea cores in the Indian Ocean (Ninkovich et al., 1978b) and on land in Malaysia and elsewhere.

At least three major eruptions have occurred at Toba (Knight et al., 1984), the latest at $0.075 \mathrm{Ma}$ (Ninkovich et al., 1978a). Ignimbrites associated with these eruptions are all calc-alkaline rhyolites $\left(68 \%\right.$ to $76 \% \mathrm{SiO}_{2}$; Chesner, 1985), are mineralogically and lithologically similar, and are distinguished primarily by magnetic polarity and chemical composition. Exposed sections through the ignimbrites consist of thick sequences of crystalrich, poorly sorted, massively bedded welded tuffs overlain by nonwelded pyroclastic flow deposits. All Toba rocks contain quartz, plagioclase $\left(A b_{69}-A b_{54}\right)$, sanidine, biotite, amphibole, orthopyroxene, magnetite, ilmenite, allanite, zircon, and apatite. Samples used in this analysis are part of a large suite being employed in a major petrological/geochemical study of Toba deposits by C. A. Chesner and W. I. Rose (in prep.).

\section{DEFORMATION MICROSTRUCTURES}

For our preliminary analysis, we have used research polarizing microscope and universal stage techniques to examine thin sections at 13 welded ignimbrites at or from within $20 \mathrm{~km}$ of the caldera, one sample (10.680) from a drill core, two pumice samples, and one welded ash collected inside the caldera. Although quartz is abundant in most of these specimens, it is typically only fractured, and planar features of the type shown in Figures $1 \mathrm{~A}$ and $1 \mathrm{~B}$ were observed in single sets in only $24(<<1 \%)$ grains in nine sections of the welded ignimbrites and in the welded ash. Orientations of the planar features with respect to the $c$ axis are shown in Figure 2, and although they are not significant statistically, these orientations correspond approximately with those (107 sets) observed by Bohor et al. (1984, 1985) and observed in other extensive studies of shocked quartz discussed above.

Local occurrences of highly and irregularly kinked and fragmented biotite crystals, such as those shown in Figures $1 C$ and 1D, are also good indicators of shock deformation during the Toba explosion. Biotite kinking of this type has been observed in granodiorite shocked by the Hardhat nuclear explosion (Cummings, 1968; Short, 1968a), in high explosive and chemical implosion experiments in the shock stress range 7-40 GPa (Short, 1968b), and in many natural impactites (e.g., Bunch, 1968; Chao, 1968; Short and Bunch, 1968). Biotites that have been heavily shocked are oxidized and converted to fine aggregates of magnetite at their boundaries; they have reduced pleochroism and birefringence near their centers (Chao, 1968) and have anomalous interference figures (Cummings, 1968). These shock-metamorphic

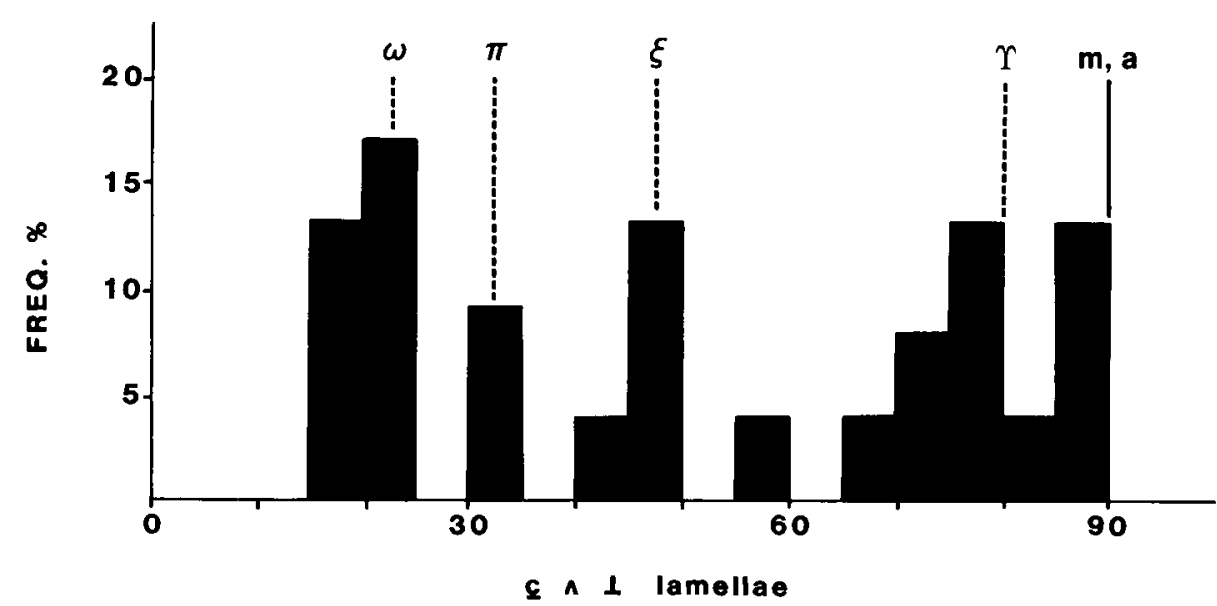

Figure 2. Histogram showing orientation with respect to $c$ axis of 24 sets of planar features in 17 Toba sections studied. Quartz crystal forms indicated are $\underline{\omega}(10 \overline{1} 3), \underline{\pi}$ (10 $\overline{1} 2), \xi(11 \overline{2} 2), \Upsilon$

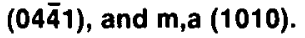


changes are observed in some of the deforrned biotites in the Toba specimens; especially pronounced are the grain-boundary magnetite aggregates.

The foregoing observations on deformed quartz and biotite, although highly suggestive, do not by themselves provide firm evidence for strong shock deformation during the Toba eruption. However, when considered together with the more widespread and betterdocumented deformation of plagioclase, there is little question that strong shock deformation has occurred. Planar features, analogous in most respects to those in quartz, are more abundant in plagioclase than in quartz in the Toba specimens examined, but their orientations have not yet been measured. Planar features in plagioclase have also been observed at some K/T sites (Bohor et al., 1985) in impactites (e.g., Bunch, 1968; Robertson et al., 1968), and in the Hardhat explosion (Short, 1968a, 1968b). They first appear at somewhat higher shock stress levels than are required for their development in quartz (Chao, 1968; Short, 1968b).

At still higher shock stress levels, a mosaic or chaotic subgrain texture develops in shocked silicates (e.g., Stoffler, 1972). These textures in plagioclase in impactites and experiments are commonly accompanied with increasing shock stress by decreases in refractive index and birefringence and by partial recrystallization and partial to total conversion to glass (e.g., Chao, 1968; Bunch, 1968; Short and Bunch, 1968; Robertson et al., 1968; Short, 1968b). A similar progression has been observed for naturally and experimentally shocked olivine (Carter et al., 1968). Examples of shock mosaicism are prodigious in all Toba samples studied when account is taken of the heterogeneities expected of shock deformations. Examples of this type of deformation are shown in Figure 3. In Figure $3 \mathrm{~A}$, typical mosaic structures of quartz showing very irregular, patchy extinction differ appreciably from the generally smooth, regular, optically homogeneous subgrain structure in recovered tectonically deformed quartz (e.g., Carter, 1976). This chaotic substructure is also shown in a plagioclase crystal in Figure 3B; incipient recrystallization, probably annealing following peak shock stresses (Carter et al., 1968), is observed near the center of the grain. Twin bands (east-west) in the plagioclase crystal of Figure $3 \mathrm{C}$ are distorted by the shock mosaic extinction zones in the crystal. The extinction zones or subgrains in this crystal and as shown in Figure 3D are somewhat more regular than the zones developed in shock experiments and in impactites, probably as a result of some annealing recovery during postshock residence in the hot ignimbrite. Microstructures of this type have not been observed in tectonically deformed plagioclase, to our knowledge. Subgrain development during dynamic recovery takes place by dislocation creep, which is high.y unlikely for the plagioclase in the Toba tectonic environment.

\section{DISCUSSION AND CONCLUSIONS}

Violent silicic volcanic explosions apparently are capable of producing high local shock stress concentrations that in the Toba ignimbrite are best manifested in shock mosaicism of plagioclase presumably in the wall rock of the caldera. The fact that microstructures in quartz are rare, however, poses an enigma that may be related to the structural and physical environment of the erupting volcano. Temperatures (based on Fe-Ti oxide data; C. A. Chesner, in pref.) at the time of the eruption were near $700^{\circ} \mathrm{C}$ as compared to near-ambient temperatures for most rocks shocked experimentally and those subjected to extraterrestrial impact. Acciordingly, differences in the nature and development of microstructures produced by shock deformation at a given stress level are expected in the two settings, and healing and/or anneal- ing may be expected in shocked materials contained within an ignimbrite flow. Some of the evidence for shock, such as perhaps shock lamellae in quartz, may be obliterated by healing during postshock residence times at high temperature, whereas more resilient microstructures in other minerals, such as plagioclase and biotite, may be altered somewhat but preserved. Alternatively, shock lamellae may not form readily in preheated shocked quartz crystals (T. Ahrens, 1985, personal commun.). If these assertions are correct, then microstructures from the Toba ignimbrites cannot explain the postulated global occurrence of shocked quartz at the $\mathrm{K} / \mathrm{T}$ boundary.

However, silicic eruptions larger than Toba may have occurred in the past (Smith, 1979). The eruption column for the youngest Toba eruption was estimated to have exceeded heights of $50 \mathrm{~km}$ (Ninkovich et al., 1978b); rapid cooling of small shocked quartz grains in the column might well preserve the microstructures, if formed. In this hypothesis, shocked quartz might occur in ash falls associated with large silicic volcanic eruptions. This possibility should be investigated thoroughly for Toba ash

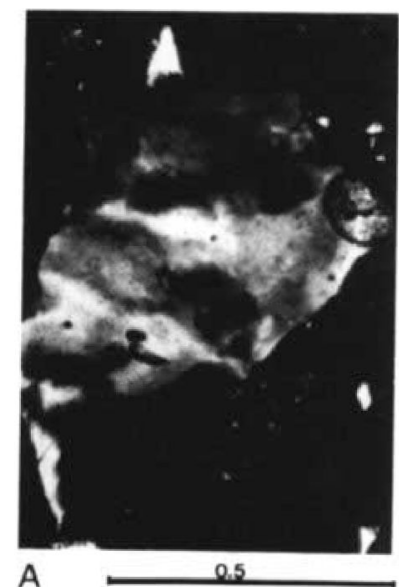

A

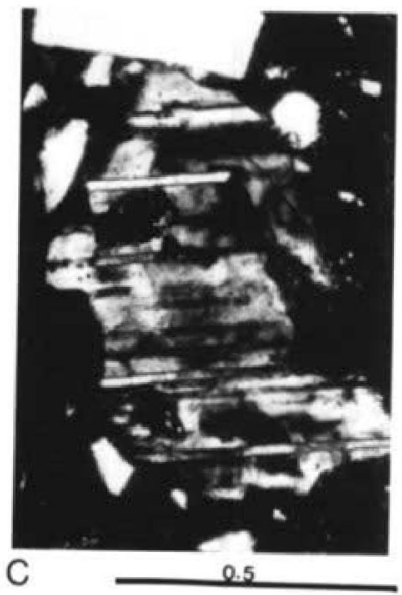

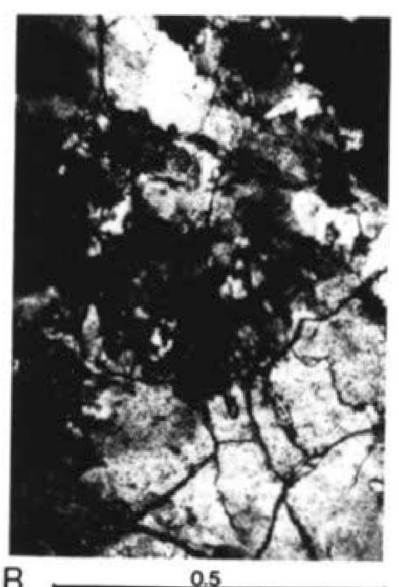

B

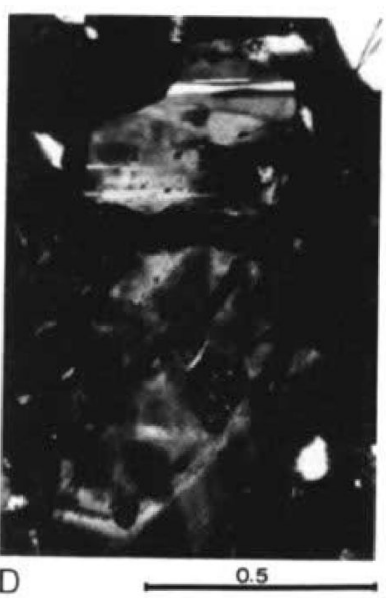

Figure 3. Photomicrographs showing shockmosaic texture in quartz and plagioclase of Toba ignimbrites; crossed nicols. Scale bars are in millimetres. A: Mosaic structure in quartz grain in section T-94B. B: Strong mosaicism and incipient recrystallization (small white grains in center) in plagioclase in specimen 10.680. C and $D$ : Partially recovered mosaic structure in plagio. clase in specimens T-65 and T-94B, respectively. 
along with the search for large calderas and impact craters that formed about $65 \mathrm{Ma}$.

Because of the differences in initial temperatures between impactites, experiments, and volcanic processes, it is difficult to estimate peak shock stress during the Toba explosion. If, however, the shock stresses are near those required to produce shock mosaicism in plagioclase at initial ambient temperatures, then local shock stress concentrations appreciably greater than $10 \mathrm{GPa}$ are indicated. Endogenous processes producing similar high shock stress levels at considerable depths appear to be required to explain shock metamorphism of the Vredefort structure, South Africa (Lilly, 1981; Schreyer, 1983).

Thus, it appears that shock stresses of large magnitude can be produced by internal processes and do not require impacts of extraterrestrial objects. Clearly, the matter of internal shock deformation merits further investigation that we hope will be stimulated by the preliminary results presented here.

\section{REFERENCES CITED}

Alvarez, L.W., Alvarez, W., Asaro, F., and Michel, H.V., 1980, Extraterrestrial cause for the Cretaceous-Tertiary extinction: Science, v. 298, p. 1095-1108.

Axelrod, D.I., 1981, Role of volcanism in climate and evolution: Geological Society of America Special Paper 185, $59 \mathrm{p}$.

Bemmelen, R.W. von, 1939, The volcano-tectonic origin of the Lake Toba (North Sumatra): De Ingenieur Nederlandsch-Indie, v. 6, p. 126-140.

Bohor, B.F., Foord, E.E., Modreski, P.J., and Triplehorn, D.M., 1984, Mineralogic evidence for an impact event at the Cretaceous-Tertiary boundary: Science, v. 224 , p. $867-869$.

Bohor, B.F., Modreski, P.J., and Foord, E.E., 1985, A search for shock-metamorphosed quartz at the $\mathrm{K} / \mathrm{T}$ boundary, in Lunar and Planetary Science Conference XVI: Houston, Texas, Lunar and Planetary Institute, Pt. 1, p. 79-80.

Bunch, T.E., 1968, Some characteristics of selected minerals from craters, in French, B.M., and Short, N.M., eds., Shock metamorphism of natural materials: Baltimore, Maryland, Mono Book Corporation, p. 413-432.

Carter, N.L., 1965, Basal quartz deformation lamellae, a criterion for recognition of impactites: American Journal of Science, v. 263, p. 786-806.

1968a, Meteoritic impact and deformation of quartz: Science, v. 160 , p. 526-628.

- 1968b, Dynamic deformation of quartz, in French, B.M., and Short, N.M., eds., Shock metamorphism of natural materials: Baltimore, Maryland, Mono Book Corporation, p. 453474.

1976, Steady state flow of rocks: Reviews of Geophysics and Space Physics, v. 14, p. 301-360.

Carter, N.L., Raleigh, C.B., and DeCarli, P.S. 1968 , Deformation of olivine in stony meteorites: Journal of Geophysical Research, v. 73, p. 5439-5461.
Chao, E.C.T., 1968, Pressure and temperature histories of impact metamorphosed rocks-based on petrographic observations, in French, B.M., and Short, N.M., eds., Shock metamorphism of natural materials: Baltimore, Maryland, Mono Book Corporation, p. 135-158.

Chesner, C.A., 1985, Geochemistry of the Toba ignimbrites: Implications on silicic magma bodies, outflow patterns, and caldera collapse [abs.]: EOS (American Geophysical Union Transactions), v. 66, p. 1141 .

Cummings, D., 1968, Shock deformation of biotite around a nuclear explosion, in French, B.M. and Short, N.M., eds., Shock metamorphism of natural materials: Baltimore, Maryland, Mono Book Corporation, p. 211-218.

Engelhardt, W.V., Horz, F., Stoffler, D., and Bertsch, W., 1968, Observations on quartz deformation in the breccias of West Clearwater Lake, Canada and the Ries Basin, Germany, in French, B.M., and Short, N.M., eds., Shock metamorphism of natural materials: Baltimore, Maryland, Mono Book Corporation, p. 475-482.

Horz, F., 1968, Statistical measurements of deformation structures and refraction indices in experimentally shock loaded quartz, in French, B.M., and Short, N.M., eds., Shock metamorphism of natural materials: Baltimore, Maryland, Mono Book Corporation, p. 243-254.

Izett, G.A., and Pillmore, C.L., 1985, Abrupt appearance of shocked quartz at the CretaceousTertiary boundary, Raton basin, Colorado and New Mexico: Geological Society of America Abstracts with Programs, v. 17, p. 617.

Kent, D.V., 1981, Asteroid extinction hypothesis: Science, v. 211, p. 648-649.

Knight, M.D., Walker, G.P.L., Caress, M.E., and Diehl, J.F., 1984, Stratigraphy of the Toba Tuffs, North Sumatra: EOS (American Geophysical Union Transactions), v. 65, p. 1134

Lilly, P.A., 1981, Shock metamorphism in the Vredefort Collar: Evidence for internal shock sources: Journal of Geophysical Research, v. 85 , p. 10689-10700.

McIntyre, D.B., 1962, Impact metamorphism at Clearwater Lake, Quebec [abs.]: Journal of Geophysical Research, v. 67, p. 1647.

McLean, D.W., 1985, Mantle degassing induced dead ocean in the Cretaceous-Tertiary transition: American Geophysical Union Geophysical Monograph 32, p. 493-503.

Ninkovich, D., Shackleton, N.J., Abdel-Monem, A.A., Obradovich, J.D., and Izett, G., 1978a, KAr age of the late Pleistocene eruption of Toba, north Sumatra: Nature, v. 276, p. 574-577.

Ninkovich, D., Sparks, R.S.J., and Ledbetter, M.T., $1978 \mathrm{~b}$, The exceptional magnitude and intensity of the Toba eruption, Sumatra: An example of the use of deep sea tephra layers as a geological tool: Bulletin Volcanologique, v. 41, p. 286-298.

Officer, C.B., and Drake, C.L., 1983, The Cretaceous-Tertiary transition: Science, v. 219, p. 1383-1397.

- 1985, Terminal Cretaceous environmental events: Science, v. 227, p. 1161-1187.

Officer, C.B., Drake, C.L., and Devine, J.D., 1985, Volcanism and Cretaceous/Tertiary extinctions: EOS (American Geophysical Union Transactions), v. 66, p. 83.
Reid, G.C., 1981, Asteroid extinction hypothesis: Science, v. 211, p. 650-653.

Robertson, P.B., Dence, M.R., and Vos, M.A., 1968, Deformation in rock-forming minerals from Canadian craters, in French, B.M., and Short, N.M., eds., Shock metamorphism of natural materials: Baltimore, Maryland, Mono Book Corporation, p. 433-452.

Schreyer, W., 1983, Metamorphism and fluid inclusions in the basement of the Vredefort Dome, South Africa: Guidelines to the origin of the structure: Journal of Petrology, v. 24, p. 26-47

Short, N.M., 1968a, Nuclear-explosion-induced microdeformation of rocks: An aid to the recognition of meteorite impact structures, in French, B.M., and Short, N.M., eds., Shock metamorphism of natural materials: Baltimore, Maryland, Mono Book Corporation, p. 185-210.

— 1968b, Experimental microdeformation of rock materials by shock pressures from laboratoryscale impacts and explosions, in French, B.M., and Short, N.M., eds., Shock metamorphism of natural materials: Baltimore, Maryland, Mono Book Corporation, p. 219-242.

Short, N.M., and Bunch, T.E., 1968, A worldwide inventory of features characteristic of rocks associated with presumed meteorite impact craters, in French, B.M., and Short, N.M., eds., Shock metamorphism of natural materials: Baltimore, Maryland, Mono Book Corporation, p. 255-266.

Smit, J., and Romein, A.J.T., 1985, A sequence of events across the Cretaceous-Tertiary boundary: Earth and Planetary Science Letters, v. 74, p. 155-170.

Smith, R. L., 1979, Ash-flow magmatism, in Chapin, C.E., and Elston, W.E., eds., Ash-flow tuffs: Geological Society of America Special Paper 180 , p. 5-25

Smith, R.L., and Bailey, R.A., 1962, Resurgent caldrons: Their relations to granitic ring complexes and large volume rhyolitic ash flow fields: International Volcanology Symposium, Tokyo, 1962 Abstracts, p. 67-68.

- 1968, Resurgent cauldrons, in Coats, R. L., Hay, R.L., and Anderson, C.A., eds., Studies in volcanology: Geological Society of America Memoir 116, p. 613-622.

Stoffler, D., 1972, Deformation and transformation of rock forming minerals by natural and experimental shock pressures, I, Behavior of minerals under shock compression: Fortschritte der Mineralogie, v. 49, p. 50-113.

\section{ACKNOWLEDGMENTS}

Supported by National Science Foundation Grants OCE-8408050 to Carter and EAR-8206685 to Rose. We thank Dennis V. Kent for providing Toba specimen 10.680 and for review of the manuscript, and an anonymous reviewer for a thorough critique of the paper

Manuscript received September 16, 1985 Revised manuscript received December 16, 1985 Manuscript accepted January 10, 1986 